\title{
$\angle S$ Research Square \\ Determination of toxic elements in meat products from Serbia packaged in tinplate cans
}

\section{Branislav Stojanović}

Ministry of Defence, Military Health Department, Belgrade, Serbia

\section{Saša Janković}

Institute of meat hygiene and technology Belgrade Serbia

\section{Vesna Đorđević}

Institute of Meat Hygiene and Technology Belgrade Serbia

\section{Sonja Marjanović}

Military Medical Academy: Vojnomedicinska akademija

\section{Dragan Vasilev}

University of Belgrade: Univerzitet u Beogradu

\section{Zdenka Stojanović}

Military Medical Academy: Vojnomedicinska akademija

\section{Milica Balaban}

University of Banja Luka Faculty of Natural Sciences and Mathematics: Univerzitet u Banjoj Luci Prirodno-matematicki fakultet

Vesna Antic ( $\square$ vantic@agrif.bg.ac.rs )

University of Belgrade: Univerzitet u Beogradu https://orcid.org/0000-0003-3283-0044

\section{Research Article}

Keywords: toxic elements, storage, tinplate packaging, canned meat, ingredients, migration

Posted Date: February 26th, 2021

DOI: https://doi.org/10.21203/rs.3.rs-271859/v1

License: (9) This work is licensed under a Creative Commons Attribution 4.0 International License. Read Full License 


\section{Abstract}

This work aimed to examine the influence of the storage period on the content of toxic elements (As, Cd, $\mathrm{Pb}$, and $\mathrm{Hg}$ ), in five types of canned meat products, which are regularly used in the Serbian Armed Forces. Cans of beef goulash (BG), pork ragout (PR), spam (SP), liver pate (LP), and meatballs in tomato sauce $(\mathrm{MB})$, produced according to military standards, and stored under regular conditions (temperature up to $\max 25^{\circ} \mathrm{C}$ and relative humidity up to max $75 \%$ ), were analyzed in this research. Meat products were made according to the special military requirements, packed in tinplate cans, and stored for up to 6 years. The highest average contents of toxic elements were found to be $10.00 \mu \mathrm{g} / \mathrm{kg}$ for arsenic in BG, $35.91 \mu \mathrm{g} / \mathrm{kg}$ for cadmium in LP, $15.04 \mu \mathrm{g} / \mathrm{kg}$ for mercury in PR, and $8.00 \mu \mathrm{g} / \mathrm{kg}$ for lead in PR. The storage period did not significantly affect the level of toxic elements, although higher concentrations were found in samples stored for more than two years. The influence of raw materials, spices, and additives on the level of toxic elements in some meat products was also examined. None of the samples contained toxic elements at levels exceeding the currently maximum permitted levels. The consumption of this type of food represents a small risk to human health because the exposure of soldiers to toxic elements, calculated as weekly intake, is far below legal PTWI/TWI limits, established by the Joint FAO/WHO Expert Committee on Food Additives (JECFA) and European Food Safety Authority (EFSA).

\section{Introduction}

Canned meat products occupy an important place in the diet of members of the Serbian Armed Forces. They are largely specific compared to products of the same type intended for civilian use in Serbia. The specificity is reflected in the quality of packaging material, application of tin and varnish, quality of basic and added ingredients, and production process, which keep pace with international food safety standards. Thanks to their specifics, they are high-quality products with preserved nutritional and energy values, sensory properties, and shelf life of at least four years.

Electrolytic tinplate is used for the production of metal packaging (cans) for the Serbian Armed Forces. The tinplate base is steel that provides good mechanical properties, while the tin coating gives a glossy appearance and protects the steel from corrosion (Arcelor Mittal 2013; Nikčević-Grassino et al. 2010). For the Serbian Armed Forces' needs, the application of tin is a minimum of $5.6 \mathrm{~g} / \mathrm{m}^{2}$ on external and internal can surfaces (E-5.6/5.6), which is twice as high as for civilian use in Serbia (Stojanović et al. 2019, 2020). Thanks to numerous advantages over other packaging types, tinplate packaging is most often used for the canned meat products. An organic epoxy-phenolic coating (varnish) is applied to protect the tinplate from external and internal corrosion. The basic property that each coating must show is stability at the sterilization temperature and according to the packaged food ingredients. The can coating must not change the food's sensory properties and should be elastic, continuous, of uniform thickness, and without porosity. An appropriate coating is of primary importance for maintaining the safety and quality of canned products. Monitoring the quality of the coating is extremely important to reduce the risk of loss of desirable product properties and the risk of contamination and negative impact on consumer health. 
For the needs of the Serbian Armed Forces, the application of varnish on the inner surfaces of the can is $6 \mathrm{~g} / \mathrm{m}^{2}$, while on external surfaces is $5 \mathrm{~g} / \mathrm{m}^{2}$ (Stojanović et al. 2019, 2020).

Contamination of food with toxic elements is a global problem, and there are justifiably growing concerns about its safety. The World Health Organization (WHO), through the Global Environment Monitoring System-Food Contamination Monitoring and Assessment Programme (GEMS/Food), encourages countries to conduct studies for assessing exposure to chemical pollutants, including toxic elements, through diet. Representative data on food consumption can be combined with contaminant concentration data to derive dietary exposure (FAO/WHO 2007). Severe numerous health problems can arise due to excessive uptake of heavy elements through the food. It is well established that more than 90-95\% of the total daily exposure to toxic heavy elements comes from the diet (Bocio et al. 2005; MartíCid et al. 2009). Canned food can be contaminated with toxic elements from raw materials, additives, and spices during the production process or by migration from packaging material. In real circumstances, consumers are often and significantly exposed to toxic elements through canned food. Arsenic is the only carcinogen in humans with registered evidence of carcinogenic risk by inhalation and ingestion, which belongs to Group 1 of carcinogens according to the International Agency for Research on Cancer (IARC 2012, 2016).

Arsenic can cause tumors of the skin, kidneys, bladder, and lungs. According to new modeling approaches, based on $0.5 \%$ increased incidence of lung cancer in humans, EFSA set the reference point, i.e., the benchmark dose lower confidence limit (BDML05) for As at $21.0 \mu \mathrm{g} / \mathrm{kg}$ bw/week (JECFA, 2011). Cadmium is also classified as a "human carcinogen" (Group 1) and is a highly toxic metal that occurs naturally in soil (IARC 2012, 2016). Tolerable weakly intake (TWI) for Cd is $2.5 \mu \mathrm{g} / \mathrm{kg} \mathrm{bw} /$ week (EFSA 2011). Similarly to cadmium, lead has no benefits in human metabolism, showing progressive toxicity (Zhu et al. 2011). Inorganic lead is classified as a probable human carcinogen (Group 2A) (IARC 2006, 2016). The lower benchmark dose $\left(B \mathrm{BML}_{10}\right)$ for nephrotoxic effects of $\mathrm{Pb}$ was set at $4.4 \mu \mathrm{g} / \mathrm{kg} \mathrm{bw} /$ week (EFSA 2012). Mercury occurs in several forms: elemental, inorganic, and organic. It is widely distributed in food at very low levels, mainly as the divalent inorganic $\left(\mathrm{Hg}^{2+}\right)$ form and organic methylmercury $\left(\mathrm{CH}_{3} \mathrm{Hg}\right)$. Elemental $\mathrm{Hg}$ and inorganic $\mathrm{Hg}$ compounds are not classified as carcinogenic to humans (Group 3) while methylmercury compounds classified as possibly carcinogenic (Group 2B) (IARC 2016), with TWI of $1.3 \mu \mathrm{g} / \mathrm{kg}$ bw/week (EFSA 2015).

Exposure to toxic elements and their harmful effects on human health has been the subject of intensive scientific research worldwide. However, data on the occurrence of toxic elements in canned food available on the Serbian market are minimal (Milenkovic et al. 2019; Novakov et al. 2017; Popovic et al. 2018; Škrbić et al. 2013), unlike numerous studies published in other countries. The largest number of papers published worldwide relate to toxic elements in canned fish (Ashraf et al. 2006; Emami Khansari et al. 2005; Hosseini et al. 2015; Kim et al. 2020; Lourenço et al. 2004; Norhazirah et al. 2020; Okyere et al. 2015; Pappalardo et al. 2015; Rodriguez-Mendivil et al. 2019; Russo et al. 2013; Shiber 2011; Sobhanardakani et al. 2018), while a relatively small number include canned meat testing (Ainerua et al. 2020; Buculei et al. 2014; European Commission 2006; Khalafalla et al. 2016; Korfali and Hamdan 2013; 
Kowalskaet al. 2020; Massadeh et al. 2018; Serbian Regulation 2019; Tuzen and Soylak 2007). Numerous studies show that eating habits greatly influence the exposure of the population to toxic elements, precisely through increased consumption of canned food. Maximum levels of $\mathrm{As}, \mathrm{Cd}, \mathrm{Pb}$, and $\mathrm{Hg}$ in food are determined by the EU Regulation (2006) and the Regulation of the Republic of Serbia (2019).

The main goal of this research was to examine the influence of the length of the storage period on the content of four toxic elements ( $\mathrm{As}, \mathrm{Cd}, \mathrm{Pb}, \mathrm{Hg}$ ) in canned meat, produced according to Serbian military standards. Five different products (BG, PR, SP, LP, and MB), stored in regular conditions, were used for the research. Concentrations of toxic elements were statistically processed by determining measures of variation, levels of significance, and correlation in relation to the length of the storage period. Further, the aim was to determine which meat product contains the highest concentration of a particular element and

to determine whether the concentrations of toxic elements exceed the maximum levels currently in force. The influence of raw materials, spices, and additives on the content of toxic elements in BG and MB was also examined. Finally, the potential risk to human health associated with the intake of toxic $\mathrm{As}, \mathrm{Cd}, \mathrm{Pb}$, and $\mathrm{Hg}$ that arises from canned meat consumption has been assessed.

\section{Experimental}

\section{Samples}

Empty tinplate cans. Empty two-piece and three-piece cans were made of electrolytic tinplate and produced in the can factory in Serbia. Two-piece and three-piece cans, cylindrical in shape, with the following dimensions, were used in the production of canned meat products: 1) two-piece cans, $\varnothing$ $73 \times 29.5$, for liver pate of $100 \mathrm{~g}$; 2) three-piece cans, $\varnothing 73 / 70 \times 43$, for spam of $150 \mathrm{~g}$, and 3) three-piece cans, $\varnothing 99 / 96 \times 63$, for beef goulash, pork ragout, and meatballs in tomato sauce of $400 \mathrm{~g}$. The tinplate quality corresponded to the Standards (European standard 2003, 2016) with additional requirements related to the thickness of the sheet, the tin's application, and the application and quality of the varnish. The tin application was at least $5.6 \mathrm{~g} / \mathrm{m}^{2}$ on the inner and outer surfaces $(E-5.6 / 5.6)$, which is twice the value compared to cans of the same type for civilian use, where the tin application is usually $2.8 \mathrm{~g} / \mathrm{m}^{/ 2}$. A layer of varnish was applied to the tin layer. All inner surfaces of the cans are lacquered with epoxyphenolic aluminum pigmented varnish with a minimum of $6 \mathrm{~g} / \mathrm{m}^{2}$, while all outer surfaces are lacquered with transparent gold varnish with a minimum of $5 \mathrm{~g} / \mathrm{m}^{2}$.

Canned meat products. Five types of canned meat products were used for testing: BG, PR, SP, LP, and MB, produced according to military requirements, in industrial plants of six different producers who had a contract with the Serbian Army in the year of production. After filling and sealing, the cans were thermally treated at the sterilization temperature by heating to $120^{\circ} \mathrm{C} / 30 \mathrm{~min}(\mathrm{LP}) ; 118^{\circ} \mathrm{C} / 0 \mathrm{~min}(\mathrm{SP}) ; 120^{\circ} / 90 \mathrm{~min}$ (BG and PR); or $118^{\circ} \mathrm{C} / 105 \mathrm{~min}(\mathrm{MB})$. The examined cans were undamaged, stored for up to 6 years in typical military facilities that provide appropriate conditions (temperature up to max $25^{\circ} \mathrm{C}$ and relative 
humidity up to max 75\%). Descriptive analysis of the packaging condition, i.e., the most significant deviations in the properties of cans, which were observed during the storage period, was performed before the analysis.

\section{Measurements}

ICP-MS. The analysis was performed by inductively coupled plasma mass spectrometry (ICP-MS), using iCapQ mass spectrometer (Thermo Scientific, Bremen, Germany). All the samples were analyzed in duplicate, and metal content was presented as an average. The cans' contents were homogenized, from which about $0.5 \mathrm{~g}$ was taken for microwave digestion, and $5 \mathrm{ml}$ of $\mathrm{HNO}_{3}$ and $1.5 \mathrm{ml} \mathrm{of} \mathrm{H}_{2} \mathrm{O}_{2}$ were added. The digested samples were filtered through nylon filters into polypropylene volumetric flasks, diluted to $100 \mathrm{~mL}$ with deionized water, and used for $\mathrm{As}, \mathrm{Cd}, \mathrm{Pb}$, and $\mathrm{Hg}$ determination. Simultaneously with the samples, an internal standard was introduced into the ICP-MS device. Before each reading of the element concentration, the system's parameters are automatically adjusted with the basic calibration solution. The differences between duplicates were $\leq 5.8 \%$. Instrumental LODs and LOQs were calculated as the concentration of the element that produced a signal three (LOD) and ten (LOQ) times higher than those of the averaged blanks. Analytical method parameters are shown in Table 1.

Table 1. Limits of detection (LOD) and quantification (LOQ), assigned and measured concentrations of the BCR-185R reference material $(n=10)$

\begin{tabular}{|c|c|c|c|c|c|c|}
\hline Element & $\begin{array}{l}\text { LOD, } \\
\mu \mathrm{g} / \mathrm{kg}\end{array}$ & $\begin{array}{l}\text { LOQ, } \\
\mu \mathrm{g} / \mathrm{kg}\end{array}$ & $\begin{array}{l}\text { Method } \\
\text { repeatability/precision, } \\
\%\end{array}$ & $\begin{array}{l}\text { Certified } \\
\text { value, }^{\#} \\
\mu g / k g\end{array}$ & $\begin{array}{l}\text { Analyzed } \\
\text { value, } \\
\mu \mathrm{g} / \mathrm{kg}\end{array}$ & $\begin{array}{l}\text { Recovery, } \\
\%\end{array}$ \\
\hline As & 1.2 & 4.0 & 3.57 & $19.3 \pm 1.4$ & $20.5 \pm 1,1$ & 106.2 \\
\hline $\mathrm{Cd}$ & 0.4 & 1.0 & 8.99 & $97.0 \pm 1.4$ & $97.9 \pm 2,6$ & 100.9 \\
\hline $\mathrm{Pb}$ & 2.0 & 4.0 & 3.65 & $62.8 \pm 1.0$ & $63.3 \pm 2,6$ & 100.8 \\
\hline $\mathrm{Hg}$ & 0.3 & 1.0 & 6.90 & - & - & - \\
\hline
\end{tabular}

The data are presented as means \pm standard deviation.

${ }^{\#}$ Certified values, given by the producer.

By analyzing certified reference material NIST 1577c (bovine liver) in each series of analyzed samples, quality control was performed. Solvents and spiked samples were included in each batch of digestion and analysis. The most abundant isotopes were used for quantification. The concentrations were within the range of the certified values for all isotopes. As no information was given regarding $\mathrm{Hg}$ content in the reference material, analytical recoveries of $93.5-106.0 \%$ were determined using spiked samples $(\mathrm{Hg}=10$ $\mathrm{mg} / \mathrm{kg} ; \mathrm{n}=10)$. 


\section{Statistcs}

In order to apply any statistical treatment, it is necessary to determine the distribution of data in the appropriate set. The Shapiro-Wilk test was used to verify the normality of the data distribution. According to the Shapiro-Wilk test, data sets that were found not to be subject to normal distribution were not further treated by statistical methods due to various influences that could have led to deviations. For data below the LOQ but above the LOD, a value between those two limits was expressed as LOQ/2. Data sets that are normally distributed are presented in the form MV \pm SD (mean \pm standard deviation) with minimum and maximum value in a given group. Statistical significance $(p)$ was determined using the Student's t-test or ANOVA analysis, depending on the set's structure. All analyzes were performed using the IBM SPSS Statistics 19 software package.

\section{Results And Discussion}

\section{RESULTS AND DISCUSSION}

The canned meat products used in this work (beef goulash-BG, pork ragout-PR, spam-SP, liver pate-LP, and the meatballs in tomato sauce-MB) were produced for the needs of the Serbian Armed Forces, according to the military standards, in industrial facilities of various manufacturers. Considering that they represent strategic foods, their quality is greatly important, starting from the cans to the finished product. On the other hand, it is crucial to monitor the migration of toxic elements into the contents of cans that have been produced according to special requirements and stored for a long time. The influence of the length of the storage period on the migration of toxic heavy elements - $\mathrm{As}, \mathrm{Cd}, \mathrm{Pb}$, and $\mathrm{Hg}$, from the tinplate packaging to the can's contents was investigated. In addition, the level of the same elements was checked in some raw materials, spices, and additives, to assess their contribution to the final content of $\mathrm{As}, \mathrm{Cd}, \mathrm{Hg}$, and $\mathrm{Pb}$ in the canned products.

\section{External appereance of cans during storage}

Cans of the same quality are provided for the production of meat products. According to the same recipe, a specific meat product was produced with different producers and stored under the same regular conditions. Changes on the outer surface of the cans during six years of storage are shown in Table 2 . Changes on the LP and MB cans had already been noticed in the third year of storage, i.e., during the defined shelf-life of 4 years. On BG cans, marbling and corrosion were determined in the first half of the fourth year of storage, while corrosion of PR cans was noticed after five years. It is interesting to note that no changes were observed on the cans of BG, PR, and LP stored for six years, indicating that factors other than the length of storage could cause corrosion.

Table 2. Changes on cans during storage 


\begin{tabular}{|c|c|c|c|c|c|c|}
\hline \multicolumn{2}{|c|}{$\begin{array}{l}\text { Period of storage } \\
\text { (year } / \text { month }=\mathrm{y} / \mathrm{m} \text { ) }\end{array}$} & \multicolumn{5}{|c|}{ Type of meat can } \\
\hline & & BG & PR & SP & LP & MB \\
\hline $\begin{array}{l}0 y / 1 m- \\
2 y / 6 m\end{array}$ & \multirow[t]{4}{*}{$\begin{array}{l}\text { While } \\
\text { shelf life }\end{array}$} & nd & nd & nd & nd & nd \\
\hline $\begin{array}{l}2 y / 6 m- \\
3 y / 0 m\end{array}$ & & nd & nd & nd & corrosion & corrosion \\
\hline $\begin{array}{l}3 y / 0 m- \\
3 y / 6 m\end{array}$ & & $\begin{array}{l}\text { marbling, } \\
\text { corrosion }\end{array}$ & $\begin{array}{l}\text { insignificant } \\
\text { damages }\end{array}$ & $\begin{array}{l}\text { insignificant } \\
\text { damages }\end{array}$ & - & - \\
\hline $\begin{array}{l}3 y / 6 m- \\
4 y / 0 m\end{array}$ & & - & nd & - & - & corrosion \\
\hline $\begin{array}{l}4 y / 0 m- \\
4 y / 6 m\end{array}$ & \multirow[t]{4}{*}{$\begin{array}{l}\text { Expired } \\
\text { shelf life }\end{array}$} & $\begin{array}{l}\text { marbling, } \\
\text { corrosion }\end{array}$ & nd & corrosion & - & - \\
\hline $\begin{array}{l}4 y / 6 m- \\
5 y / 0 m\end{array}$ & & - & - & corrosion & corrosion & - \\
\hline $\begin{array}{l}5 y / 0 m- \\
5 y / 6 m\end{array}$ & & nd & corrosion & corrosion & corrosion & - \\
\hline $\begin{array}{l}5 y / 6 m- \\
6 y / 0 m\end{array}$ & & nd & nd & $\begin{array}{l}\text { insignificant } \\
\text { damages }\end{array}$ & nd & - \\
\hline
\end{tabular}

nd= changes not detected

Concentration of toxic elements in the content of cans

One of the ways how toxic elements can enter the human body is through canned food, although people can also be exposed to them through contaminated water, air, and soil. There is a large amount of literature data on the adverse influences of toxic elements on human health (Azeh Engwa et al. 2019; Fu and Xi 2020; Jaishankar et al. 2014; Järup 2003; Morais et al. 2012; Olmedo et al. 2013; Rehman et al. 2017). Some of the harmful effects include: impaired renal ( $\mathrm{Pb}, \mathrm{Cd}, \mathrm{Hg}$ ) and liver ( $\mathrm{Pb}$ and $\mathrm{Cd}$ ) function, decreased cognitive function $(\mathrm{Pb}, \mathrm{Hg})$, weakened reproductive system $(\mathrm{Cd}, \mathrm{Pb})$, hypertension $(\mathrm{Cd})$, neurological problems $(\mathrm{Hg}, \mathrm{Pb})$, teratogenic $(\mathrm{Hg})$, and cancerogenic effects $(\mathrm{Cd})$.

In this work, the values of $\mathrm{As}, \mathrm{Cd}, \mathrm{Hg}$, and $\mathrm{Pb}$ were determined in the content of five types of canned meat products during the storage period from 15 days to 6 years. Although the shelf life of canned meat products stored for more than four years has expired, these cans have also been taken for testing to determine the extent of changes in toxic metals concentration. The results show that toxic elements were present in the contents of all types of canned meat products but not in significant concentrations in each storage period (Table 3).

Table 3. Content of toxic elements in canned meat foods 


\begin{tabular}{|c|c|c|c|c|c|c|}
\hline \multirow[t]{2}{*}{ Sample } & \multirow[t]{2}{*}{ Producer } & \multirow[t]{2}{*}{ Period of storage $(y / m)^{a)}$} & \multicolumn{4}{|c|}{ Toxic elements, $\mu \mathrm{g} / \mathrm{kg}$} \\
\hline & & & As & Cd & $\mathrm{Hg}$ & $\mathrm{Pb}$ \\
\hline \multirow[t]{7}{*}{ BG } & \multirow[t]{4}{*}{ A } & $0 / 3$ & 4.00 & 1.00 & nd & nd \\
\hline & & $0 / 11$ & $<4$ & nd & nd & nd \\
\hline & & $2 / 2$ & 10.00 & 1.00 & $<1$ & $<4$ \\
\hline & & $3 / 2$ & 5.39 & $<1$ & 6.71 & $<4$ \\
\hline & \multirow[t]{3}{*}{$\mathrm{B}$} & $4 / 0$ & 5.22 & 1.55 & 4.58 & nd \\
\hline & & $5 / 1$ & 5.13 & $<1$ & 9.48 & $<4$ \\
\hline & & $5 / 9$ & 5.19 & $<1$ & 8.48 & 6.00 \\
\hline \multirow[t]{7}{*}{ PR } & \multirow[t]{4}{*}{ A } & $0 / 3$ & nd & 1.00 & $<1$ & nd \\
\hline & & $0 / 6$ & nd & nd & nd & nd \\
\hline & & $2 / 2$ & $<4$ & nd & $<1$ & nd \\
\hline & & $3 / 2$ & $<4$ & $<1$ & 6.49 & $<4$ \\
\hline & \multirow[t]{3}{*}{ B } & $4 / 0$ & $<4$ & $<1$ & 11.72 & $<4$ \\
\hline & & $5 / 1$ & $<4$ & 2.18 & 15.04 & 8.00 \\
\hline & & $5 / 9$ & 9.33 & 2.03 & 8.29 & $<4$ \\
\hline \multirow[t]{7}{*}{ SP } & \multirow[t]{3}{*}{ C } & $0 / 8$ & $<4$ & $<1$ & $<1$ & nd \\
\hline & & $1 / 1$ & 5.66 & 3.50 & 5.10 & $<4$ \\
\hline & & $2 / 1$ & $<4$ & 1.16 & 2.12 & 6.00 \\
\hline & B & $3 / 1$ & 4.58 & 13.28 & 11.44 & 5.00 \\
\hline & $D$ & $4 / 4$ & nd & 1.55 & nd & $<4$ \\
\hline & B & $5 / 0$ & $<4$ & 1.00 & $<1$ & nd \\
\hline & $\mathrm{E}$ & $6 / 0$ & 4.96 & 1.49 & 4.56 & $<4$ \\
\hline \multirow[t]{4}{*}{ LP } & \multirow[t]{3}{*}{$C$} & $0 / 7$ & $<4$ & 6.00 & $<1$ & $<4$ \\
\hline & & $1 / 1$ & 5.47 & 2.48 & 1.72 & nd \\
\hline & & $2 / 6$ & $<4$ & 10.20 & 7.01 & $<4$ \\
\hline & $B$ & $3 / 0$ & 4.70 & 35.91 & 6.63 & 4.00 \\
\hline
\end{tabular}




\begin{tabular}{|ccccccc|} 
& D & $4 / 4$ & nd & 11.13 & $<1$ & nd \\
& B & $5 / 0$ & nd & 8.00 & $<1$ & $<4$ \\
\hline MB & & $6 / 0$ & $<4$ & 6.71 & 3.55 & $<4$ \\
& & $0 / 1$ & $<4$ & 3.00 & nd & nd \\
& F & $1 / 10$ & $<4$ & 7.00 & nd & $<4$ \\
& & $2 / 8$ & 5.00 & 4.00 & $<1$ & nd \\
& & $3 / 9$ & $<4$ & 2.00 & $<1$ & $<4$ \\
\hline
\end{tabular}

a) $y / m=y e a r s / m o n t h s$

b) nd=not detected

In BG cans, the Pb value exceeded LOQ $(4 \mu \mathrm{g} / \mathrm{kg})$ only in the sample that was stored for the most prolonged period $(5 \mathrm{y} / 5 \mathrm{~m})$ and amounted $6 \mu \mathrm{g} / \mathrm{kg}$, while Cd values were at the LOQ limit or lower $(<1$ $\mu \mathrm{g} / \mathrm{kg}$ ) in all storage periods. Because of that, the $\mathrm{Pb}$ and $\mathrm{Cd}$ data were not statistically processed, unlike the values of As and $\mathrm{Hg}$. For similar reasons, only the $\mathrm{Hg}$ values in PR samples were processed by statistical analysis and $\mathrm{Cd}$ and $\mathrm{Hg}$ data in SP samples. The data of $\mathrm{Cd}$ and $\mathrm{Hg}$ were also statistically processed for LP samples. For the MB samples, only the values of Cd were above LOQ $(>1 \mu \mathrm{g} / \mathrm{kg})$ and therefore statistically processed. Heavy metals were not detected (nd) in about $20 \%$ of cans $(26 / 128$, Table 3). The mean values of As, Cd, and $\mathrm{Hg}$, with standard deviations (SD) in different meat products, are shown in Fig 1. It was noticed that there were no statistically significant changes concerning the mean concentrations of toxic elements at the significance level of $99 \%(p>0.01)$.

Data are presented as mean \pm SD.

To ensure food safety, the European Commission (2006) has established maximum acceptable residual levels for toxic elements, except for As, where no limits have yet been set. Serbian Regulation (2019) has set maximum $\mathrm{Cd}, \mathrm{Pb}$, and $\mathrm{Hg}$ levels in fresh meat, meat products, offal, and kidneys, which are in line with EU Regulation (Table 4). Serbian Regulation gives maximum values for As as well (Table 4), unlike European legislation. The obtained levels of all toxic elements in analyzed canned meat products produced for the Serbian Armed Forces were below both legal national and EU limits (European Commission Regulation 2006; Serbian Regulation 2019).

Table 4. Maximum acceptable residual levels for toxic elements, established by Serbian Regulation 


\begin{tabular}{|c|c|}
\hline $\begin{array}{l}\text { Toxic } \\
\text { element }\end{array}$ & Serbian Regulation (2019), $\mu \mathrm{g} / \mathrm{kg}$ \\
\hline \multirow[t]{3}{*}{ As } & 100 (fresh meat) \\
\hline & 100 (meat products) \\
\hline & 500 (offal) \\
\hline \multirow[t]{3}{*}{$\mathrm{Cd}$} & 50 (fresh meat) \\
\hline & 500 (offal) \\
\hline & 1000 (kidneys) \\
\hline \multirow[t]{2}{*}{$\mathrm{Hg}$} & 30 (fresh meat) \\
\hline & 100 (offal) \\
\hline \multirow[t]{2}{*}{$\mathrm{Pb}$} & 100 (fresh meat) \\
\hline & 500 (offal) \\
\hline
\end{tabular}

\section{Arsenic}

It is well known that arsenic enters the human body through water, which is the most important source of exposure, followed by air and food (Brandon et al. 2014; Kim et al. 2015). Our results showed that As varied significantly in BG samples, from below LOQ (first year of storage) to $10.00 \mu \mathrm{g} / \mathrm{kg}$ (more than two years of storage). The values of As were not detected or were below LOQ in all PR cans, except in the sample with the most prolonged storage period (less than six years), when it was $9.33 \mu \mathrm{g} / \mathrm{kg}$. In SP and LP samples, the highest values were detected at the beginning of the second year of storage $-5.66 \mu \mathrm{g} / \mathrm{kg}$ and $5.47 \mu \mathrm{g} / \mathrm{kg}$. The highest value in MB samples was $5.00 \mu \mathrm{g} / \mathrm{kg}$ in the third year of storage. In a significant number of samples, in all five types of canned meat, the values of As were not detected or were below LOQ, as shown in Table 3. Based on the obtained results, no correlation can be established between the length of the storage period and the concentration of As. The values of As found in canned meat products were significantly lower than the permitted values for meat products $(100 \mu \mathrm{g} / \mathrm{kg})$ and offal (500 $\mu \mathrm{g} / \mathrm{kg})$, prescribed by the Serbian Regulation (2019).

\section{Cadmium}

The cadmium level in food is influenced by factors such as type of food, growing plant conditions, anthropogenic contamination of air, soil, water systems, etc (Tchounwouet al. 2012). The results of our study show that the highest Cd value in BG samples was $1.55 \mu \mathrm{g} / \mathrm{kg}$, after four years of storage; in PR samples, it was $2.18 \mu \mathrm{g} / \mathrm{kg}$, after five years, while in SP samples concentration of As was $13.28 \mu \mathrm{g} / \mathrm{kg}$, after three years of storage. In LP and MB samples, Cd values were above the LOQ level in all storage periods. In the case of LP samples, the values ranged from $2.48 \mu \mathrm{g} / \mathrm{kg}$, after one year of storage, to 35.91 $\mu \mathrm{g} / \mathrm{kg}$, after three years of storage. In MB samples, the As value ranged from $2.00 \mu \mathrm{g} / \mathrm{kg}$, after three years, 
up to $7.00 \mu \mathrm{g} / \mathrm{kg}$, after one year. Mean Cd values for all types of cans were significantly below the permitted values for meat $(50 \mu \mathrm{g} / \mathrm{kg})$, liver $(500 \mu \mathrm{g} / \mathrm{kg})$, and kidneys $(1000 \mu \mathrm{g} / \mathrm{kg})$, prescribed by Serbian Regulation (2019) (Fig 1). The highest value of Cd was detected in LP samples, which is not surprising considering that the liver is the target organ of cadmium. This was also confirmed in the work of Akan et al. (2010), where Cd concentrations in the liver and kidneys ranged from 70 to $760 \mu \mathrm{g} / \mathrm{kg}$. Based on the obtained results, it can be concluded that there is no strong correlation between the detected Cd value and the length of the storage period, although, in longer periods of storage, higher concentrations are detected.

\section{Mercury}

According to the literature data, the largest intake of mercury in the human body is through food, of which about $90 \%$ comes from sea fish and fish products; part of the intake is through cereals, flour, milk, fruits, and vegetables, while the intake through meat and offal is about $9 \%$ (Tchounwou et al. 2012). In our study, in one-half of the samples, $\mathrm{Hg}$ was below LOQ or not detected. The highest $\mathrm{Hg}$ values in BG and PR samples were after five years of storage $(9.48 \mu \mathrm{g} / \mathrm{kg}$ and $15.04 \mu \mathrm{g} / \mathrm{kg}$, respectively). In SP samples, the highest $\mathrm{Hg}$ value was after three years of storage $(11.44 \mu \mathrm{g} / \mathrm{kg})$, while in LP samples, the highest value was detected after more than two years $(7.01 \mu \mathrm{g} / \mathrm{kg})$. In all MB samples, the values of $\mathrm{Hg}$ were below LOQ. The mean values of $\mathrm{Hg}$ were significantly lower in all types of canned meat, related to the maximum values: $30 \mu \mathrm{g} / \mathrm{kg}$ for fresh meat and $100 \mu \mathrm{g} / \mathrm{kg}$ for offal and meat products, prescribed by the Serbian Regulation (2019). It can be concluded that there is no strong correlation between the storage period and the obtained mercury values, although in more extended storage periods can be observed increased $\mathrm{Hg}$ concentration in almost all meat products.

\section{Lead}

The primary sources of lead to which the general population is exposed are beer, cereals, flour, potatoes, fruits, and vegetables (Tchounwou et al. 2012). Pb values in all BG cans were below LOQ or not detected in our work except for the sample with the most prolonged storage period of 6 years $(6.00 \mu \mathrm{g} / \mathrm{kg})$. In all PR samples, $\mathrm{Pb}$ values were similarly below $\mathrm{LOQ}$, except for the sample stored for more than five years $(8.00 \mu \mathrm{g} / \mathrm{kg})$. The Pb values were below LOQ for the SP samples stored for less than one year, while for the samples stored for more than two years, the Pb level was above $5 \mu \mathrm{g} / \mathrm{kg}$. For the samples stored for more than four years, the level of $\mathrm{Pb}$ again dropped below LOQ. Pb values in all LP samples were below LOQ or not detected, except for the sample stored for three years $(4.00 \mu \mathrm{g} / \mathrm{kg})$. In MB cans, the value of $\mathrm{Pb}$ in all samples was below LOQ. A significant number of samples with nd values or values below LOQ indicated that the length of the storage period did not affect $\mathrm{Pb}$ concentration. Detected $\mathrm{Pb}$ values are significantly lower than the maximum values prescribed by the Serbian Regulation (2019): $100 \mu \mathrm{g} / \mathrm{kg}$ for fresh meat and $500 \mu \mathrm{g} / \mathrm{kg}$ for offal.

Concentration of toxic elements in raw materials, spices and additives

Page $11 / 23$ 
Although the storage period does not significantly affect the toxic elements' values, it can be observed that higher concentrations are usually found in samples stored for more than two years. The highest As value was found in BG stored more than two years $(10.00 \mu \mathrm{g} / \mathrm{kg})$, the highest Cd value in LP stored three years $(35.91 \mu \mathrm{g} / \mathrm{kg})$, while the highest $\mathrm{Hg}$ and $\mathrm{Pb}$ values were found in PR stored five years (15.04 and $8.00 \mu \mathrm{g} / \mathrm{kg}$, respectively). The migration of toxic elements from metal packaging into the contents of cans is most likely influenced by the quality and continuity of protective coatings (tin and varnish) on cans' inner surfaces, which decrease during storage. However, the concentration of toxic elements is also affected by the natural pollution of raw materials, spices, additives, and secondary pollution related to the production process. Similar observations are also given by other authors (Buculei et al. 2014; Khalafalla et al. 2016), who, in addition to the storage period, list many other factors that affect the content of toxic elements in canned food. These facts are also confirmed by Khalafalla et al., who examined the presence of $\mathrm{Pb}, \mathrm{Cd}, \mathrm{Hg}$, and $\mathrm{Sn}$ in canned products (chicken, beef, frankfurter, salted beef), with an emphasis on sources of contamination and limits (Khalafalla et al. 2016). Therefore, the content of toxic elements in raw materials, spices, and additives for the production of BG and MB (samples stored 3 and 1 month, respectively) was examined in order to roughly assess their contribution to the concentration of $\mathrm{As}, \mathrm{Cd}$, $\mathrm{Hg}$ and $\mathrm{Pb}$ in the tested food. In the case of BG cans, beef and beef tallow (raw materials), dry onion and red ground pepper (spices), as well as kitchen salt (additive) were tested. Concentrations of all toxic elements in raw materials and additives were below the $\mathrm{LOQ}$, while $\mathrm{Cd}$ and $\mathrm{Pb}$ were detected in spices. A very high Cd concentration in red ground pepper $(163 \mu \mathrm{g} / \mathrm{kg})$ was particularly noteworthy (Table 5).

In the case of MB cans, beef and pork meat and tomato sauce (starting raw materials), dry onion, red ground pepper, flour, sugar, dish supplement, food additive, and kitchen salt were tested. Results are presented in Table 6. Concentrations of all toxic elements were below LOQ in beef and pork, while $\mathrm{Pb}$ and Cd were detected in tomato sauce (20.0 and $10.0 \mu \mathrm{g} / \mathrm{kg}$, respectively). Higher concentrations of As, Cd, and $\mathrm{Pb}$ were found in spices and additives, with especially significant values of $\mathrm{Pb}$ in dish supplement $(250 \mu \mathrm{g} / \mathrm{kg})$ and $\mathrm{Cd}$ in red ground pepper and additive (150 and $70 \mu \mathrm{g} / \mathrm{kg}$, respectively).

Table 5. Toxic elements in raw materials, spices, and additives for the production of beef goulash

\begin{tabular}{|lllll|}
\hline Raw materials, spices and & \multicolumn{5}{c|}{ Toxic elements, $\mu \mathrm{g} / \mathrm{kg}$} \\
\cline { 2 - 6 } additives & As & $\mathrm{Cd}$ & $\mathrm{Hg}$ & $\mathrm{Pb}$ \\
\hline Beef meat & $<4$ & $<1$ & $<1$ & $<4$ \\
\hline Beef tallow & $<4$ & $<1$ & $<1$ & $<4$ \\
\hline Dry onion & $<4$ & 19.0 & $<1$ & 18.0 \\
Red ground pepper & $<4$ & 163.0 & $<1$ & 24.0 \\
\hline Kitchen salt & $<4$ & $<1$ & $<1$ & $<4$ \\
\hline
\end{tabular}


Based on the determined concentration values, it can be concluded that the raw material composition, and especially spices and additives, potentially can affect the concentration of toxic elements in the finished product. However, the concentrations of cadmium and lead in BG and MB were far below the values allowed by Serbian Regulation (2019). It can be concluded that even a very high level of these toxic elements in spices and additives does not significantly affect their concentration in the final product. The reason for this is a tiny amount of spices and additives that are added to dishes.

Nevertheless, the quality and safety of spices and additives in terms of toxic elements must be constantly monitored to prevent harmful effects on consumer health.

Table 6. Values of toxic elements in raw materials, spices, and additives for the production of meatballs in tomato sauce

\begin{tabular}{|lllll|}
\hline Raw materials, spices and & \multicolumn{5}{l|}{ Toxic elements, $\mu \mathrm{g} / \mathrm{kg}$} \\
\cline { 2 - 5 } additives & As & $\mathbf{C d}$ & $\mathrm{Hg}$ & $\mathrm{Pb}$ \\
\hline Beef meat & $<4$ & $<1$ & $<1$ & $<4$ \\
\hline Pork meat & $<4$ & $<1$ & $<1$ & $<4$ \\
\hline Tomato sauce & $<4$ & 10.0 & $<1$ & 20.0 \\
\hline Dry onion & 40.0 & 20.0 & $<1$ & 20.0 \\
\hline Red ground pepper & 40.0 & 150.0 & $<1$ & 20.0 \\
\hline Minced onion & 10.0 & $<1$ & $<1$ & 20.0 \\
\hline Minced pepper & $<4$ & $<1$ & 4.0 & 30.0 \\
\hline Dish supplement & 10.0 & 40.0 & $<1$ & 250.0 \\
\hline Additive & 10.0 & 70.0 & $<1$ & $<4$ \\
\hline Flour & 10.0 & 10.0 & $<1$ & 50.0 \\
\hline Sugar & $<4$ & $<1$ & $<1$ & 20.0 \\
\hline Kitchen salt & $<4$ & $<1$ & $<1$ & $<4$ \\
\hline
\end{tabular}

Finally, meat cans were produced in six industrial facilities, which had a concluded contract with the Serbian Armed Forces in a certain year. The producers are marked with letters A, B, C, D, E, and F (Table 3). The meat cans of the same type were produced by the same recipes in all facilities; however, the quality of the entire production process in a particular facility can also affect the final quality of the food and the level of toxic metals.

Influence of toxic elements from canned food on the health of consumers 
Considering the health risks derived from toxic $\mathrm{Cd}, \mathrm{Pb}, \mathrm{Hg}$, and $\mathrm{As}$, regular monitoring and updates of dietary intakes of heavy elements are required. In order to estimate dietary exposures of the solders of Serbian Armed Forces to $\mathrm{Cd}, \mathrm{Pb}, \mathrm{Hg}$, and $\mathrm{As}$, through consumption of the canned meat food examined in this work, the mean concentration data were combined with dietary information and the average body weight of 1000 individual consumers. The soldiers' average body weight was $70.6 \mathrm{~kg}$, with minimal and maximal 50.0 and $94.0 \mathrm{~kg}$ values, respectively. According to the planned diet, in regular conditions, soldiers consume $160 \mathrm{~g}$ of GG, $400 \mathrm{~g}$ of PR, $450 \mathrm{~g}$ of SP, 300 grams of LP, and $400 \mathrm{~g}$ of MB, monthly. In emergency conditions, the amount of food consumed doubles.

Based on canned food consumption values, the exposure of soldiers to toxic elements was calculated and expressed as weekly intake per kg body weight. The results are shown in Table 7, together with provisional tolerable weakly intakes of toxic elements (PTWI), established by the Joint FAO/WHO Expert Committee on Food Additives (JECFA 2014) and tolerable weekly intakes (TWI), established by EFSA $(2011,2015)$. Since EFSA and other food safety authorities no longer recommend the use of previously established PTWIs for As and Pb, the BMDL (Benchmark Dose Lower Confidence Limit) values were used instead: BMDL05 of $21.0 \mu \mathrm{g} / \mathrm{kg}$ bw/week for lung cancer in human (As) and BMDL10 of $4.4 \mu \mathrm{g} / \mathrm{kg}$ bw/week for nephrotoxic effects (Pb) (EFSA 2012). The contribution to the TWI (\%TWI) or BMDL (\%BMDL) was calculated as the ratio of weekly intake (WI) of a specific metal through canned food examined in this work and TWI or BDML for the particular toxic element. Weekly intake of a metal $(\mu \mathrm{g} / \mathrm{kg}$ bw/week) was calculated in the following way:

\section{$\mathbf{W I}[\mu \mathrm{g} / \mathrm{kg}$ bw $/$ week $]=\sum \frac{\mathrm{TE}_{\text {conc }}(\mu \mathrm{g} / \mathrm{kg}) \times \mathrm{MC}(\mathrm{kg} / \mathrm{month})}{\mathrm{bw}(\mathrm{kg}) \times 4}$}

Where $\mathrm{TE}_{\text {conc }}$ is the mean concentration of particular toxic element $(\mu \mathrm{g} / \mathrm{kg})$; $\mathrm{MC}$ is monthly consumption of specific canned food $(\mathrm{kg})$; and bw is the mean soldgers body waight value $(70.6 \mathrm{~kg})$.

Table 7. Intake of toxic elements calculated from the mean concentration data of this work and combined with dietary information and the average body weight of 1000 individual consumers 


\begin{tabular}{|c|c|c|c|c|c|c|c|}
\hline \multirow[t]{4}{*}{$\begin{array}{l}\text { Type } \\
\text { of food }\end{array}$} & \multirow{4}{*}{$\begin{array}{l}\text { Mean } \\
\text { value, } \\
\mu \mathrm{g} / \mathrm{kg}\end{array}$} & \multirow{3}{*}{\multicolumn{2}{|c|}{$\begin{array}{l}\text { Monthly } \\
\text { consumption, } \\
\text { kg }\end{array}$}} & \multicolumn{4}{|c|}{$\begin{array}{l}\text { Intake of toxic elements through } \\
\text { canned meat products }\end{array}$} \\
\hline & & & & \multirow{2}{*}{\multicolumn{2}{|c|}{$\begin{array}{l}M l^{\mathrm{a})} \\
\mu \mathrm{g}(\mathrm{kg} \mathrm{bw})^{-1} \text { month }^{-1}\end{array}$}} & \multirow{2}{*}{\multicolumn{2}{|c|}{$\begin{array}{l}W l^{b)} \\
\mu g / k g \text { bw/week }\end{array}$}} \\
\hline & & & & & & & \\
\hline & & Regular & Emergency & Regular & Emergency & Regular & Emergency \\
\hline \multicolumn{8}{|l|}{ As } \\
\hline BG & 4.99 & 0.160 & 0.320 & 0.0113 & 0.0226 & 0.0028 & 0.0056 \\
\hline PR & 2.00 & 0.400 & 0.800 & 0.0113 & 0.0226 & 0.0028 & 0.0056 \\
\hline SP & 2.00 & 0.450 & 0.900 & 0.0127 & 0.0254 & 0.0032 & 0.0064 \\
\hline LP & 2.00 & 0.300 & 0.600 & 0.0085 & 0.0170 & 0.0021 & 0.0042 \\
\hline MB & 2.00 & 0.400 & 0.800 & 0.0113 & 0.0226 & 0.0028 & 0.0056 \\
\hline Total & & & & 0.0551 & 0.1102 & 0.0139 & 0.0274 \\
\hline PTWI $\left.{ }^{c}\right)$ & & & & & & \multicolumn{2}{|c|}{$15.0 \mu \mathrm{g} / \mathrm{kg} \mathrm{bw} /$ week } \\
\hline $\mathrm{BMDL}_{05}$ & & & & & & \multicolumn{2}{|c|}{$21.0 \mu \mathrm{g} / \mathrm{kg} \mathrm{bw} /$ week } \\
\hline \multirow{2}{*}{$\begin{array}{l}\% \text { PTWI or } \% \\
\text { BMDL }_{05}\end{array}$} & & & & & & 0.09 & 0.18 \\
\hline & & & & & & 0.07 & 0.13 \\
\hline \multicolumn{8}{|l|}{$\mathrm{Pb}$} \\
\hline BG & 2.00 & 0.160 & 0.320 & 0.0045 & 0.0090 & 0.0011 & 0.0022 \\
\hline PR & 2.00 & 0.400 & 0.800 & 0.0113 & 0.0226 & 0.0028 & 0.0056 \\
\hline SP & 2.00 & 0.450 & 0.900 & 0.0127 & 0.0254 & 0.0032 & 0.0064 \\
\hline LP & 2.00 & 0.300 & 0.600 & 0.0085 & 0.0170 & 0.0021 & 0.0042 \\
\hline MB & 2.00 & 0.400 & 0.800 & 0.0113 & 0.0226 & 0.0028 & 0.0056 \\
\hline Total & & & & 0.0483 & 0.0966 & 0.0120 & 0.0240 \\
\hline PTWI $\left.{ }^{c}\right)$ & & & & & & \multicolumn{2}{|c|}{$25.0 \mu \mathrm{g} / \mathrm{kg} \mathrm{bw} /$ week } \\
\hline $\mathrm{BMDL}_{10}$ & & & & & & \multicolumn{2}{|c|}{$4.4 \mu \mathrm{g} / \mathrm{kg} \mathrm{bw} /$ week } \\
\hline \multirow{2}{*}{$\begin{array}{l}\% \mathrm{PTWI} \text { or } \% \\
\text { BMDL }_{10}\end{array}$} & & & & & & 0.05 & 0.10 \\
\hline & & & & & & 0.27 & 0.54 \\
\hline Cd & & & & & & & \\
\hline
\end{tabular}




\begin{tabular}{|c|c|c|c|c|c|c|c|}
\hline BG & 0.50 & 0.160 & 0.320 & 0.0011 & 0.0022 & 0.0003 & 0.0006 \\
\hline PR & 0.50 & 0.400 & 0.800 & 0.0028 & 0.0056 & 0.0007 & 0.0014 \\
\hline SP & 3.21 & 0.450 & 0.900 & 0.0205 & 0.0410 & 0.0051 & 0.0102 \\
\hline LP & 11.49 & 0.300 & 0.600 & 0.0488 & 0.0976 & 0.0122 & 0.0244 \\
\hline MB & 4.00 & 0.400 & 0.800 & 0.0227 & 0.0454 & 0.0057 & 0.0114 \\
\hline Total & & & & 0.0959 & 0.1918 & 0.0240 & 0.0480 \\
\hline TWle) & & & & & & \multicolumn{2}{|c|}{$2.5 \mu \mathrm{g} / \mathrm{kg} \mathrm{bw} /$ week } \\
\hline$\%$ TWI & & & & & & 0.10 & 0.20 \\
\hline \multicolumn{8}{|l|}{$\mathrm{Hg}$} \\
\hline BG & 4.39 & 0.160 & 0.320 & 0.0099 & 0.0198 & 0.0025 & 0.0050 \\
\hline PR & 6.15 & 0.400 & 0.800 & 0,0348 & 0.0696 & 0.0087 & 0.0174 \\
\hline SP & 3.53 & 0.450 & 0.900 & 0.0225 & 0.0450 & 0.0056 & 0.0112 \\
\hline LP & 2.23 & 0.300 & 0.600 & 0.0095 & 0.0190 & 0.0024 & 0.0048 \\
\hline MB & 0.50 & 0.400 & 0.800 & 0.0028 & 0.0056 & 0.0007 & 0.0014 \\
\hline Total & & & & 0.0795 & 0.1590 & 0.0199 & 0.0398 \\
\hline TWle) & & & & & & \multicolumn{2}{|c|}{$1.3 \mu \mathrm{g} / \mathrm{kg} \mathrm{bw} /$ week } \\
\hline$\%$ TWI & & & & & & 1.53 & 3.06 \\
\hline
\end{tabular}

a) MI - monthly intake

b)WI- weekly intake

c) Former PTWI values withdrawn. Not possible to establish a new PTWI that would be considered safe for health (JECFA 2014)

e)Established by EFSA CONTAM Panel $(2011,2015)$

It can be concluded from Table 7 that the intake of toxic elements through canned meat is significantly lower than the established values of TWI/BMDL. The highest \%TDI value is only $1.53 \mathrm{for} \mathrm{Hg}$, while in emergencies, it amounts and 3.06. However, it is essential to note that soldiers can also ingest toxic elements by consuming other types of food and other sources. Therefore, the daily intake of toxic elements is undoubtedly significantly higher. Since toxic elements cause many diseases, it is necessary and crucial to continually monitor canned food quality as a possible source of toxic elements.

\section{Conclusions}


No significant relationship was observed between the storage period and the concentration of toxic elements in the tested samples of canned meat. Moreover, there were no statistically significant changes concerning the mean concentrations at the significance level of $99 \%(p>0.01)$. However, the level of individual elements increased in some samples, especially during longer storage times, such as: arsenic in BG samples (up to $10.00 \mu \mathrm{g} / \mathrm{kg}$ ); cadmium in SP and LP samples (up to $35.91 \mu \mathrm{g} / \mathrm{kg}$ ), and mercury in PR and SP samples (up to $15.04 \mu \mathrm{g} / \mathrm{kg}$ ), indicating possible migration of toxic metals from tinplate packaging. The concentration of toxic elements did not exceed the maximum permitted levels currently in force by Serbian and EU legislation. The level of all toxic elements was below currents limits in raw materials, as well. However, certain toxic elements were somewhat increased in some spices and additives, such as $\mathrm{Cd}$ and $\mathrm{Pb}$. It can conclude that the consumption of canned meat products represents a small health risk to the Serbian Armed Forces consumers because the weekly intake of toxic elements is far below legal PTWI/TWI limits. However, constant estimation of contaminants intake through food is necessary for risk evaluation. Such exposure evaluations are useful when deciding on the regulation of chemical contaminants and food products' safety. The intake of $\mathrm{As}, \mathrm{Cd}, \mathrm{Hg}$, and $\mathrm{Pb}$ through the diet is of great public concern. It must be monitored continuously and rapidly updated to identify possible health risks of toxic elements in different countries. Based on the results obtained in this work, it can be concluded that the level of toxic elements in canned food that soldiers regularly have on the menu does not currently pose a risk to their health and that there is no reason to change their eating habits.

\section{Declarations}

\section{Acknowledgements}

This research was done within the contract on financing scientific research in 2020 between the University of Belgrade-Faculty of Agriculture and the Ministry of Education, Science and Technological Development of the Republic of Serbia, No:

451-03-68/2020-14/200116.

Ethics approval and consent to participate - Not applicable

Consent for publication - Not applicable

Availability of data and materials - The datasets used and/or analysed during the current study are available from the corresponding author on reasonable request.

Competing interests - The authors declare that they have no competing interests

Funding - Ministry of Education, Science and Technological Development of the Republic of Serbia

\section{Authors' contributions}

BS - Investigation 
SJ - Formal analysis

$\mathrm{V} \oplus$ - Methodology

SM - Validation

DV - Conceptualization

ZS - Resources

MB - Visualization

\section{VA - Project administration, Supervision, Writing - original draft}

Acknowledgements - Acknowledgement to the Ministry of Education, Science and Technological Development of the Republic of Serbia

Authors' information (optional)

\section{References}

Ainerua MO, Erhunmwunse N, Tongo I, Ezemonye L (2020) Food toxicity assessment of selected canned foods in Nigeria. Toxicol Res 36:45-58. https://doi.org/10.1007/s43188-019-00001-9

Akan JC, Abdulrahman FI, Sodipo OA, Chiroma YA (2010) Distribution of heavy metals in the liver, kidney and meat of beef, mutton, caprine and chicken from Kasuwan Shanu market in Maiduguri Metropolis, Borno State, Nigeria. Res J Appl Sci Eng Technol 2:743-748. https://maxwellsci.com/print/rjaset/v2-743748.pdf

Arcelor Mittal (2013) Steel for Packaging, Product catalogue.

https://packaging.arcelormittal.com/repository2/Unassigned/ArcelorMittal\%20Packaging\%20\%20product\%20catalogue.pdf

Ashraf W, Seddigi Z, Abulkibash A, Khalid M (2006) Levels of Selected Metals in Canned Fish Consumed in Kingdom of Saudi Arabia. Environ Monit Assess 117:271-279 https://doi.org/10.1007/s10661-0060989-5

Azeh Engwa G, Udoka Ferdinand P, Nweke Nwalo F, Unachukwu M (2019) Mechanism and Health Effects of Heavy Metal Toxicity in Humans. Poisoning in the Modern World - New Tricks for an Old Dog? IntechOpen. https://doi:10.5772/intechopen.82511

Bocio A, Nadal M, Domingo JL (2005) Human exposure to metals through the diet in Tarragona, Spain. Biol Trace Elem Res 104:193-201. https://doi.org/10.1405/BTER:104:3:193 
Brandon EFA, Janssen, PJCM, de Wit-Bos L (2014) Arsenic: bioaccessibility from seaweed and rice, dietary exposure calculations and risk assessment. Food Addit Contam Part A Chem Anal Control Expo Risk Assess 31:1993-2003. http://doi:10.1080/19440049.2014.974687

Buculei A, Amariei S, Oroian M, Gutt G, Gaceu L, Birca A (2014) Metals migration between product and metallic package in canned meat. LWT 58:364-394. https://doi.org/10.1016/j.lwt.2013.06.003

EFSA (European Food Safety Authority) (2012) Lead dietary exposure in the European population. EFSA J 10:2831. https://doi:10.2903/j.efsa.2012.2831

EFSA (European Food Safety Authority) (2015) Statement on the benefits of fish/seafood consumption compared to the risks of methylmercury in fish/seafood. EFSA J 13:3982. https://doi:10.2903/j.efsa.2015.3982

EFSA Panel on Contaminants in the Food Chain (CONTAM) (2011) Scientific Opinion on tolerable weekly intake for cadmium. EFSA J 9:1975.

https://efsa.onlinelibrary.wiley.com/doi/pdf/10.2903/j.efsa.2011.1975

Emami Khansari F, Ghazi-Khansari M, Abdollahi M (2005) Heavy metals content of canned tuna fish. Food Chem 93:293-296. https://doi.org/10.1016/j.foodchem.2004.09.025

European Commission (2006) Commission Regulation (EC) No 1881/2006 of 19 December 2006. Setting maximum levels for certain contaminants in foodstuff. OJEU L364:5-24. https://eur-lex.europa.eu/legalcontent/EN/ALL/?uri=CELEX\%3A32006R1881

European standard (2003) Cold reduced tinmill products - Electrolytic tinplate and electrolytic chromium/chromium oxide coated steel. EN 10202:2001/AC:2003.

https://standards.iteh.ai/catalog/standards/cen/4a0e075f-47a9-4e6b-84ea-6f0cec6e2b73/en-102022001-ac-2003

European standard (2016) Cold reduced tinmill products - Blackplate. EN 10205:2016. https://standards.iteh.ai/catalog/standards/cen/d1786453-6a65-4f1a-8b66-6a77f2390eb7/en-102052016

FAO/WHO (2007) Food Balance Sheet. http://www.fao.org/faostat/en/\#data/FBS (last update 22 December 2020; accessed January 2021).

Fu Z, Xi S (2020) The Effects of Heavy Metals on Human Metabolism. Toxicol Mech Methods 30:167176. https://doi.org/10.1080/15376516.2019.1701594

Hosseini SV, Sobhanardakani S, Miandare HK, Harsij M, Regenstein JM (2015) Determination of toxic (Pb, $\mathrm{Cd})$ and essential (Zn, Mn) metals in canned tuna fish produced in Iran. J Environ Health Sci Eng 13:59. https://doi:10.1186/s40201-015-0215-x 
IARC (International Agency for Research on Cancer) (2006) Inorganic and organic lead compounds. https://publications.iarc.fr/Book-And-Report-Series/larc-Monographs-On-The-Identification-OfCarcinogenic-Hazards-To-Humans/Inorganic-And-Organic-Lead-Compounds-2006

IARC (International Agency for Research on Cancer) (2012) Arsenic, metals, fibres and dusts. IARC Monographs on the Evaluation of Carcinogenic Risk of Chemicals to Humans.

https://publications.iarc.fr/Book-And-Report-Series/larc-Monographs-On-The-Identification-OfCarcinogenic-Hazards-To-Humans/Arsenic-Metals-Fibres-And-Dusts-2012

IARC (International Agency for Research on Cancer) (2016) Agents Classified by the IARC Monographs. https://monographs.iarc.fr/list-of-classifications/

Jaishankar M, Tseten T, Anbalagan N, Mathew BB, Beeregowda KN (2014) Toxicity, mechanism and health effects of some heavy metals. Interdiscip Toxicol 7:60-72. https://doi:10.2478/intox-2014-0009

Järup L (2003) Hazards of heavy metal contamination. Br Med Bull 68:167-182.

https://doi:10.1093/bmb/ldg032

JECFA (2014) Evaluations of the Joint FAO/WHO Expert Committee on Food Additives. Includes all updates up to the 79th JECFA (June 2014). https://apps.who.int/food-additives-contaminants-jecfadatabase/chemical.aspx?chemID $=3594$

JECFA (Joint FAO/WHO Expert Committee on Food Additives) (2011) Evaluation of Certain Food Additives and Contaminants. https://apps.who.int/iris/handle/10665/44514

Khalafalla FA, Ali FHM, Hassan ARHA, Basta SE (2016) Residues of lead, cadmium, mercury and tin in canned meat products from Egypt: an emphasis on permissible limits and sources of contamination. $J$ Verbrauch Lebensm 11:139-143. https://doi.org/10.1007/s00003-016-1020-x

Kim HS, Kim YJ, Seo YR (2015) An Overview of Carcinogenic Heavy Metal: Molecular Toxicity Mechanism and Prevention. J Cancer Prev 20:232-240. http://dx.doi.org/10.15430/JCP.2015.20.4.232

Kim T-H, Kim JH, Le Kim MD, Suh WD, Kim JE, Yeon, HJ, Park YS, Kim S-H, Oh Y-H, Jo G-H (2020) Exposure assessment and safe intake guidelines for heavy metals in consumed fishery products in the Republic of Korea. Environ Sci Pollut Res 27:33042-33051. https://doi.org/10.1007/s11356-020-09624-0

Korfali SI, Hamdan WA (2013) Essential and toxic metals in Lebanese marketed canned food: impact of metal cans. J Food Res 2:19-30. http://citeseerx.ist.psu.edu/viewdoc/download? doi=10.1.1.828.7986\&rep=rep1\&type=pdf

Kowalska G, Pankiewicz U, Kowalski R (2020) Determination of the Level of Selected Elements in Canned Meat and Fish and Risk Assessment for Consumer Health. J Anal Methods Chem. https://doi.org/10.1155/2020/2148794 
Lourenço HM, Afonso C, Martins MF, Lino AR, Nunes ML (2004) Levels of Toxic Metals in Canned Seafood. J Aquat Food Prod Technol 13:117-125. https://doi:10.1300/j030v13n03_11

Martí-Cid R, Perelló G, Domingo J L (2009) Dietary Exposure to Metals by Individuals Living Near a Hazardous Waste Incinerator in Catalonia, Spain: Temporal Trend. Biol Trace Elem Res 131:245-254. https://10.1007/s12011-009-8368-z

Massadeh AM, Al-Massaedh AAT, Kharibeh S (2018) Determination of selected elements in canned food sold in Jordan markets. Environ Sci Pollut Res 25:3501-3509. https://doi.org/10.1007/s11356-017-04655

Milenkovic B, Stajic JM, Stojic N, Pucarevic M, Strbac S (2019) Evaluation of heavy metals and radionuclides in fish and seafood products. Chemosphere 229:324-331.

https://doi.org/10.1016/j.chemosphere.2019.04.189

Morais S, e Costa FG, Lourdes Pereir M de (2012) Heavy Metals and Human Health. Environmental Health - Emerging Issues and Practice. IntechOpen. https://doi:10.5772/29869

Nikčević-Grassino A, Grabarić Z, Pezzani A, Squitieri G, Berković K (2010) Corrosion inhibition with different protective layers in tinplate cans for food preservation. J Sci Food Agric 90:2419-2426. https://doi.org/10.1002/jsfa.4101

Norhazirah AA, Shazili NAM, Kamaruzzaman Y, Sim SF, Ahmad A, Ong MC (2020) Heavy metals in tune species meat and potential consumer health risk: A Review. IOP Conference Series: Earth and Environmental Science. https://doi:10.1088/1755-1315/494/1/012013

Novakov NJ, Mihaljev ŽA, Kartalović BD, Blagojević BJ, Petrović JM, Ćirković MA, Rogan DR (2017) Heavy metals and PAHs in canned fish supplies on the Serbian market. Food Addit Contam B 10:208-215. http://dx.doi.org/10.1080/19393210.2017.1322150

Okyere H, Voegborlo RB, Agorku SE (2015) Human exposure to mercury, lead and cadmium through consumption of canned mackerel, tuna, pilchard and sardine. Food Chem 179:331-335. https://doi.org/10.1016/j.foodchem.2015.01.040

Olmedo P, Pla A, Hernández AF, Barbier F, Ayouni L, Gil F (2013) Determination of toxic elements (mercury, cadmium, lead, tin and arsenic) in fish and shellfish samples. Risk assessment for the consumers. Environ Int 59:63-72. https://doi:10.1016/j.envint.2013.05.005

Pappalardo AM, Copat C, Ferrito V, Grasso A, Ferrante M (2017) Heavy metal content and molecular species identification in canned tuna: Insights into human food safety. Mol Med Rep 15:3430-3439. https://doi.org/10.4092/mmr.2017.6396

Popovic AR, Djinovic-Stojanovic JM, Djordjevic DS, Relic DJ, Vranic DV, Milijasevic MP, Pezo LL (2018) Levels of toxic elements in canned fish from the Serbian markets and their health risks assessment. J 
Food Compos Anal 67:70-76. https://doi.org/10.1016/j.jfca.2018.01.003

Rehman K, Fatima F, Waheed I, Akash MSH (2017) Prevalence of exposure of heavy metals and their impact on health consequences. J Cell Biochem 119:157-184. https://doi.org/10.1002/jcb.26234

Rodriguez-Mendivil DD, Garcia-Flores E, Temores-Pena J, Wakida FT (2019) Health Risk Assessment of Some Heavy Metals from Canned Tuna and Fish in Tijuana, Mexico, Health Scope 8:e78956.

https://doi:10.5812/jhealthscope.78956

Russo R, Lo Voi A, De Simone A, Serpr FP, Anastasio A, Pepe T, Cacase D, Severino L (2013) Heavy Metals in Canned Tuna from Italian Markets. J Food Prot 76:355-359. https://doi:10.4315/0362-028x.jfp-12-346

Serbian Regulation (2019) Maximum allowed contents of contaminants in food. Official Bulletin of the Republic of Serbia 81/2019.

Shiber JG (2011) Arsenic, cadmium, lead and mercury in canned sardines commercially available in eastern Kentucky, USA. Mar Pollut Bull 62:66-72. https://doi.org/10.1016/j.marpolbul.2010.09.008

Škrbić B, Živančev J, Mrmoš N (2013) Concentrations of arsenic, cadmium and lead in selected foodstuffs from Serbian market basket: Estimated intake by the population from the Serbia. Food Chem Toxicol 58:440-448. https://doi.org/10.1016/j.fct.2013.05.026

Sobhanardakani S, Hosseini SV, Tayebi L (2018) Heavy Metals Contamination of Canned Fish and Related Health Implications in Iran. Turk J Fish Aqua Sci 18:951-957. https://doi:10.4194/1303-2712v18_8_03

Stojanović B, Radović Lj, Natić D, Dodevska M, Vraštanović-Pavičević G, Balaban $M$, Lević S, Petrović T, Antić V (2019) Influence of a storage conditions on migration of bisphenol A from epoxy-phenolic coating to canned meat products. J Serb Chem Soc 84:397-409.

https://doi.org/10.2298/JSC181015100S

Stojanović B, Radović Lj, Natić D, Dodevska M, Vraštanović-Pavičević G, Balaban M, Stojanović Z, Antić V (2020) Migration of bisphenol A into food simulants and meat rations during initial time of storage. Packag Technol Sci 33:75-82. https://doi.org/10.1002/pts.2485

Tchounwou PB, Yedjou CG, Patlolla AK, Sutton DJ (2012) Heavy Metal Toxicity and the Environment. In: Luch A (ed) Molecular, Clinical and Environmental Toxicology. Experientia Supplementum, Springer, Basel. https://doi.org/10.1007/978-3-7643-8340-4_6

Tuzen M, Soylak M (2007) Evaluation of trace element contents in canned foods marketed from Turkey. Food Chem 102:1089-1095. https://doi.org/10.1016/j.foodchem.2006.06.048

Zhu F, Fan W, Wang X, Qu L, Yao S (2011). Health risk assessment of eight heavy metals in nine varieties of edible vegetable oils consumed in China. Food Chem Toxicol 49:3081-3085. 
Figures

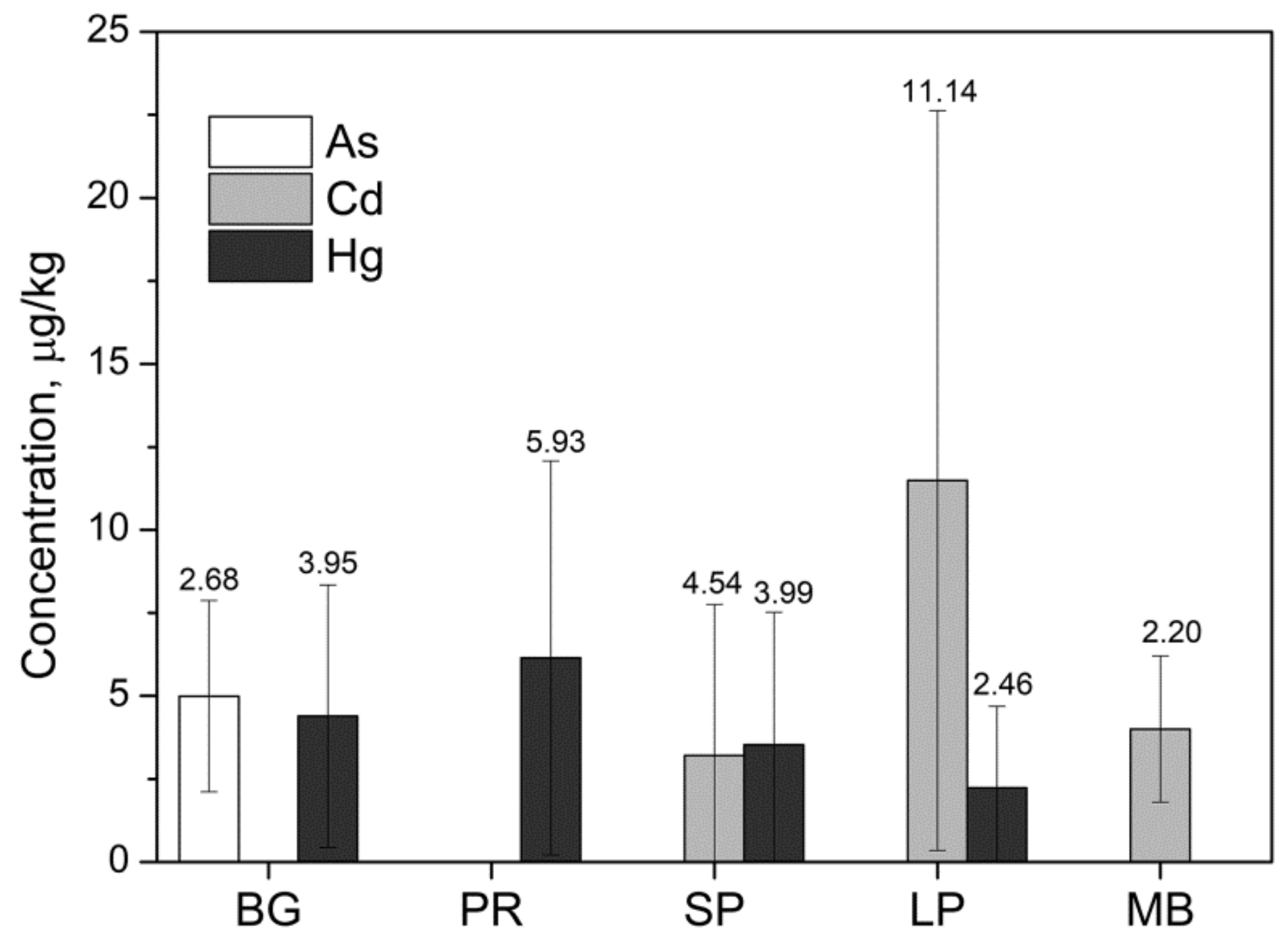

Figure 1

The mean values of $\mathrm{As}, \mathrm{Cd}$ and $\mathrm{Hg}$ in different meat products. Data are presented as mean $\pm \mathrm{SD}$. 